\title{
IRF8 wt Allele
}

National Cancer Institute

\section{Source}

National Cancer Institute. IRF8 wt Allele. NCI Thesaurus. Code C104555.

Human IRF8 wild-type allele is located in the vicinity of $16 q 24.1$ and is approximately 24 $\mathrm{kb}$ in length. This allele, which encodes interferon regulatory factor 8 protein, is involved in the modulation of interferon and interferon-inducible gene expression. 